\title{
The Effect of Temulawak Extract on Alkohol Fermentation from Molase Substrate by Saccharomyces cerevisiae
}

\section{P. Kianto Atmodjo*, Birgitta Narindri, Adam Harsono dan Aan Edison}

Fakultas Teknobiologi Universitas Atma Jaya Yogyakarta, Jl. Babarsari 44 Yogyakarta

E-mail:kianto@mail.uajy.ac.id atau pariatmodjo@gmail.com *Penulis untuk korespondensi

\begin{abstract}
High dose temulawak (Curcuma xanthorrhiza Roxb.) extract has been reported as antimicrobial. On the other hand, temulawak was used as apetite and herb drug. The aim of this research was to find out the effect of temulawak extract on alcohol fermentation especially of Saccharomyces cerevisiae growth and alcohol production. One kilogram temulawak was boiled in 2-3 liter water. The filtrate $(10,20,30,40 \mathrm{ml})$ was added to molase solution $(10 \%)$. One gram of Saccharomyce cerevisiae commercial was added. The fermentation processed in room temperature for seven days. The parameter was total cell, ratio of lived or dead cell, carbodioxide production, sugar reduction, and alcohol content. The result showed there were increasing of yeast cell, sugar consumption, and carbondioxide production, but the alcohol production was decreased. It concluded that temulawak extract was not antiyeast and the effect on fermentation product was positive.
\end{abstract}

Keywords: molase, alcohol, yeast, sugar consumption

\begin{abstract}
Abstrak
Temulawak dimanfaatkan untuk meningkatkan nafsu makan dan pelindung hati bagi manusia. Ekstrak Temulawak memiliki potensi sebagai antimikrobia dalam konsentrasi yang besar. Penelitian bertujuan untuk mengetahui pengaruh penambahan sari temulawak dalam proses fermentasi alkohol dari molase menggunakan Saccharomyces cerevisiae komersial, dan berharap adanya peningkatan konsumsi gula- molase yang diiringi peningkatan alkohol oelah adanya peningkatan nafsu makan khamir. Substrat larutan molase 30\% sebanyak $300 \mathrm{ml}$ ditambah sari temulawak pekat $(10,20,30,40 \mathrm{ml} /$ per $300 \mathrm{ml})$ diulang dua kali, kemudian ditambah 1 gram Saccharomyces cerevisiae lalu diinkubasikan dengan kondisi suhu kamar dan karbondioksida ditampung dalam akuades. Parameter yang diukur adalah total sel, pH, kadar gula metode spektrofotometri, kadar karbondioksida secara titrimetri, dan total akolhol metode gas kromatografi setelah tujuh hari fermentasi. Hasil menunjukkan bahwa ada perubahan yangbtidak signifikan pada total sel khamir, pH dan residu gula, sedangkan perubahan yang nyata pada produksi karbodioksida (meningkat sampai tiga kali lipat), dan alkohol ( menurun sampai $3 \%$ ) pada pada penambahan sari temulawak 20 dan $40 \mathrm{ml}$. Simpulannya sari temulawak tidak membunuh Saccharomyces cerevisiae dan menyebabkan perubahan fermentasi alkohol akibat penambahan sari temulawak, namun tidak ada pola yang jelas.
\end{abstract}

Kata kunci: Temulawak, molase, Saccharomyces cerevisiae, alkohol, konsumsi gula

Diterima: 13 Agustus 2016, disetujui: 30 September 2016

\section{Pendahuluan}

Temulawak (Curcuma xanthoriza Roxb) merupakan sejenis rempah yang banyak digunakan sebagai obat, sumber karbohidrat, bahan penyedap masakan dan minuman, serta pewarna alami untuk makanan, dan kosmetika (Ramdja $d k k$., 2009). Temulawak mengandung zat kuning kurkuminoid, minyak atsiri, pati, protein, lemak, sellulosa dan mineral. Rimpang temulawak mengandung $27,62 \%$ zat tepung, $1,6 \%-2,2 \%$ kurkumin dan $9 \%-11 \%$ minyak atsiri (Adila $d k k$., 2013). Komponen utama yang terpenting yaitu zat tepung dan minyak atsiri, ginjal serta anti inflamasi. Manfaat lain dari rimpang tanaman ini adalah sebagai obat meningkatkan nafsu makan dan meningkatkan kekebalan tubuh (Prasetyorini $d k k$., 2011). Penelitian Adipratama (2009) menyimpulkan bahwa ekstrak etanol temulawak dapat 
meningkatkan sistem pertahanan tubuh dengan meningkatkan total dan diferensiasi leukosit darah ayam. Sebaliknya penelitian Adilia dkk (2013) menyatakan bahwa temulawak juga memiliki daya antibiotik terhadap beberapa bakteri tertentu, sehingga dapat dimanfaatkan untuk mengurangi bakteri atau khamir liar yang sering menggangu proses fermentasi.

Potensi dan kemampuan temulawak dalam meningkatkan nafsu makan akan diujicobakan kepada khamir Saccharomyeces cerevisiae yang berperan dalam proses fermentasi alkohol Bergman (2001). Menurut Ho dan Powell (2014),pertumbuhan Saccharomyces dipengaruhi selain faktor suhu, juga oleh adanya penambahan nutrisi yaitu unsur C sebagai sumber carbon, unsur $\mathrm{N}$ yang diperoleh dari penambahan urea, amonium, pepton, mineral dan vitamin. Proses fermentasi alkohol umumnya menggunakan bahan baku molase dan buah. Hasil fermentasi Alkohol menunjukkan tingkat efisiensi yang rendah. Kadar alkohol yang diperoleh dari molase kurang dari $10 \%$, dan bila menggunakan bahan baku buah atau cairan buah lebih sedikit alkoholnya yaitu 3\%. Hasil penelitian Ismaryana dkk (2012), kandungan alkohol sebesar 5-6\% diperoleh dari fermentasi Alkohol oleh $S$. cerevisae pada substrat glukosa $30 \%$. Kecilnya alkohol yang dihasilkan, karena khamir terganggu pertumbuhan dan aktivitasnya oleh adanya alkohol yang dihasilkan. Untuk itu perlu usaha pemberian perlakuan yang mampu meningkatkan daya tahan tubuh khamir. Usaha untuk meningkatkan produksi alkohol ini telah banyak diupayakan antara lain dengan rekayasa genetik, rekayasa medium dan rekayasa faktor lingkungan fisik (Ismaryana $d k k$., 2012).

Di sisi lain pemerintah saat ini sedang menggalakkan produksi bahan bakar alternatif, untuk menggantikan bahan bakar minyak yang semakin langka, diantaranya adalah alkohol atau etanol ini yang dapat diproduksi secara berkelanjutan menggunakan teknologi tradisional maupun kekinian (Ho dan Powell, 2013). Oleh karena itu, perlu dilakukan usahausaha terkait peningkatan produksi alkohol secara terus menerus dengan memanfaatkan kearifan lokal diantaranya jamu atau herbal seperti temulawak yang dipercaya dapat meningkatkan kekuatan tubuh dan nafsu makan. Adapun penelitian temulawak sebagai bahan fermentasi alkohol maupun sebagai pemacu proses fermentasi belum banyak dilakukan dan masih sebatas kepercayaan masyarakat sehingga perlu diteliti untuk memberikan bukti-bukti ilmiah. Salah satu penelitian temulawak berkaitan dengan fermentasi alkohol dilakukan oleh Pinem (1998) yang hasil masih belum memuaskan.

Penelitian ini bertujuan mengetahui pengaruh penambahan ekstrak temulawak terhadap pembentukan alkohol pada proses fermentasi yang berbahan molase menggunakan khamir S. cerevisisae. Adapun manfaat dari penelitian adalah untuk memberikan solusi alternatif pada industri alkohol yang menggunakan basis fermentasi untuk proses produksinya, dan mampu untuk meningkatkan efisiensi proses fermentasi alkohol, sehingga akan meningkatkan kesejahteraan dan mengurangi limbah.

\section{Metode Penelitian}

\section{Bahan dan Alat}

Bahan berupa temulawak kering berupa keping kering bersih, warna kuning cerah, tidak berjamur dibeli di Pasar Beringharjo Yogyakarta. Molase dari pabrik gula Madukismo Yogyakarta. Benih Saccharomyces cerevisiae berupa fermipan komersial kering. Alat fermentasi berupa botol plastik yang polong berukuran $500 \mathrm{ml}$, spectrometer, alat titrimetric, dan alat kromatografi gas Shimidzu.

\section{Waktu dan Tempat penelitian}

Penelitian ini dilaksanakan di laboratorium Teknobioindustri Fakultas Teknobiologi Universitas Atma Jaya Yogyakarta untuk proses fermentasinya, dan di laboratorium Kimia Analisa jurusan Kimia Fakultas Matematika dan Pengetahuan Alam Universitas Gadjah Mada untuk analisis alkohol menggunakan kromatografi gas.

\section{Pembuatan Ekstrak Temulawak}

Temulawak berupa keeping temulawak ditimbang dan dipotong-potong seukuran 5-10 $\mathrm{mm}$ sebanyak satu $\mathrm{kg}$ ditambah air 2 liter dimask sampai mendidih dan airnya tinggal sekitar satu 
liter. Kemudian airnya disaring dan ditampung dalam botol sebagai ekstrak air temulawak.

\section{Persiapan molasse sebagai bahan baku}

Molase diencerkan menggunakan aquades steril menjadi larutan molase $10 \%$, lalu ditambah $30 \mathrm{ml}$ sari taoge kacang hijau (1:2), $\mathrm{pH}$ dibuat mencapai titik isoelektrik yaitu sekitar 2,8-3,2 kemudian dipanaskan sampai mendidih selama 5 menit. Molase didinginkan pada suhu ruang. Setelah itu larutan molase dimasukkan botol sambil disaring menggunakan kain saring untuk memisahkan kotoran yang ada. Larutan molase ini disimpan dalam botol tertutup.

\section{Pelaksanaan Fermentasi Alkohol}

Prosedur fermentasi etanol menggunakan modifikasi metode Wardani dan Fenty (2013). Untuk mengetahui pengaruh konsentrasi sari temulawak terhadap produksi alkohol dari molase, disiapkan 10 botol fermentasi ukur 500 $\mathrm{ml}$ diisi larutan molase $10 \%$ sebanyak $300 \mathrm{ml}$, lalu ditambahkan ektrak temulawak dengan variasi 10, 20, 30 dan $40 \mathrm{ml}$ tiap dua botol. Selanjutnya ditambahkan benih Saccharomyces cerevisiae sebanyak 1 gram. Botol ditutup dengan kondisi ada selang untuk mengalirkan udara ke botol kecil (100 ml) yang disii air $50 \mathrm{ml}$ untuk menampung karbodioksida, Fermentasi dilakukan pada suhu $30^{\circ} \mathrm{C}$, selama satu minggu, kemudian dihitung banyaknya sel, bentuk dan ukuran khamir, perubahan $\mathrm{pH}$, penurunan gula reduksi setiap 24 jam, dan analisis kadar etanol setiap 24 jam.

\section{Analisa produk}

Pengujian produk hasil fermentasi tetes tebu meliputi analisis $\mathrm{pH}$ menggunakan $\mathrm{pH}$ meter, total sel khamir menggunakan hemasitometer, karbondioksida terlarut menggunakan titrimetric, residu gula metode Nelson Somogy, dan kadar alkohol menggunakan gas kromatografi (Ceirwyn, 1995).

\section{Analisa Data}

Data yang diperoleh dianalisa variansi menggunakan ANAVA dilanjutkan penentuan beda nyata menggunakan tes LSD menggunakan program SPSS.

\section{Hasil dan Pembahasan}

Menurut Sebayang (2006), dan Simanjuntak (2009), tetes tebu atau yang dikenal sebagai Molase merupakan produk sampingan yang berbentuk cairan kental berwarna cokelat dari industri pengolahan gula tebu atau gula bit yang masih mengandung gula dan asam-asam organik. Kandungan sukrosa dalam molase amat tinggi, berkisar $48-55 \%$ sehingga sangat baik digunakan sebagai substrat untuk pembuatan etanol. Molase ini digunakan oleh pengrajin alkohol di daerah Bekonang Surakarta sebagai bahan baku pembuatan alkohol secara tradisional Molase ini juga digunakan oleh salah satu pabrik alkohol di daerah Surakarta sebagai bahan baku industri alkohol, karena harganya relatif murah dan ketersediaan melimpah. Selama ini produksi alkohol menggunkan bahan baku molase hasil alkoholnya berkisar 5-10\%, dan ada harapan untuk peningkatan alkohol di atas $10 \%$.

Tabel 1. Hasil fermentasi alkohol pada penambahan sari temulawak pada hari ke tujuh

\begin{tabular}{cccccccc}
\hline \hline $\begin{array}{c}\text { Penambahan Sari } \\
\text { temulawak ml }\end{array}$ & $\begin{array}{c}\text { Sisa gula } \\
\mathbf{m g} / \mathbf{1 0 0} \mathbf{~ m l}\end{array}$ & $\begin{array}{c}\text { Produksi } \\
\mathbf{C O}_{\mathbf{2}} \mathbf{~ p p m}\end{array}$ & $\mathbf{p H}$ & $\begin{array}{c}\text { Sel Hidup } \\
\mathbf{1 0} \mathbf{5} / \mathbf{m l}\end{array}$ & $\begin{array}{c}\text { Sel mati } \\
\mathbf{1 0} \text { / } \mathbf{m l}\end{array}$ & $\begin{array}{c}\text { Total Sel } \\
\mathbf{1 0} \mathbf{5} \text { sel/ml }\end{array}$ & $\begin{array}{c}\text { Kandungan } \\
\text { alkohol \% }\end{array}$ \\
\hline \hline 0 & $34,49 \mathrm{a}$ & $2308 \mathrm{a}$ & $3,35 \mathrm{a}$ & $3,59 \mathrm{a}$ & $6,69 \mathrm{a}$ & $10,28 \mathrm{a}$ & $9,69 \mathrm{a}$ \\
10 & $32,38 \mathrm{a}$ & $5386 \mathrm{c}$ & $3,49 \mathrm{a}$ & $4,87 \mathrm{~b}$ & $4,59 \mathrm{~d}$ & $9,78 \mathrm{a}$ & $7,76 \mathrm{c}$ \\
20 & $32.27 \mathrm{a}$ & $5590 \mathrm{c}$ & $3,59 \mathrm{a}$ & $5,68 \mathrm{c}$ & $5,25 \mathrm{c}$ & $10,93 \mathrm{a}$ & $6,50 \mathrm{~d}$ \\
30 & $32,74 \mathrm{a}$ & $3463 \mathrm{~b}$ & $3,71 \mathrm{a}$ & $3,82 \mathrm{a}$ & $6,58 b$ & $10,40 \mathrm{a}$ & $8.49 \mathrm{~b}$ \\
40 & $32.02 \mathrm{a}$ & $3461 \mathrm{~b}$ & $3,73 \mathrm{a}$ & $5,89 \mathrm{c}$ & $5,48 \mathrm{c}$ & $11,37 \mathrm{a}$ & $6,67 \mathrm{~d}$ \\
\hline \hline
\end{tabular}

Keterangan angka pada kolom yang sama, yang diikuti huruf yang sama menunjukkan tidak beda nyata 
Harapan tersebut ternyata belum dapat dijawab melalui penelitian ini, karena penambahan sari temulawak ke dalam larutan molase sebagai bahan baku fermentasi alkohol belum memberikan hasil yang memuaskan. Karena justru perlakukan kontrol pada penelitian ini menunjukkan kinerja yang paling baik. Pada kontrol hasil yang diperoleh adalah kandungan alkohol 9,69\% mendekati nilai maksimal yang diperoleh industri, didukung pertumbuhan sel khamir yang paling tinggi untuk yang mati $\left(3,3510^{5} \mathrm{sel} / \mathrm{ml}\right)$, dan sel hidupnya paling rendah $\left(3,59 \quad 10^{5} \mathrm{sel} / \mathrm{ml}\right)$. Adanya kehidupan sel khamir ditunjang oleh penggunaan sari kecambah kacang hijau sebagai sumber nitrogen dan nutrient lain yang dibutuhkan. Kondisi ini memperlihatkan bahwa pada penelitian ini proses fermentasinya telah berjalan baik (Sebayang, 2006; Juwita, 2012)

Pada proses fermentasi alkohol gula akan diubah oleh khamir menjadi sel baru, karbon dioksida, dan alkohol, serta senyawa seperti asetaldehida bila prosesnya tidak sempurna. Adanya penambahan sari atau ekstrak air temulawak membuat proses fermentasi yang terjadi meningkatkan konsumsi gula, hasil karbondioksida dan sel khamir. Peningkatannya belum ada pola yang jelas dan nyata. Untuk konsumsi gula oleh khamir paling tinggi pada penambahan temulawak $40 \mathrm{ml}$ yang ditunjukkan residu gula reduksi paling kecil yaitu 3,27 $\mathrm{mg} / 100 \mathrm{ml}$, hal ini membuktikan bahwa temulawak sebagai penambah nafsu makan pada mamalia terutama manusia, juga berlaku bagi organisme uniseluler seperti khamir (Sjoekoer $d k k ., 2013)$.

Peningkatan konsumsi gula diiringi dengan peningkatan karbondioksida yang dihasilkan.Namun hasil karbondioksida yang terbesar pada penambahan temulawak 10 dan 20 $\mathrm{ml}$, sedangkan terendah pada kontrol. Karbondioksida yang dihasilkan menunjukkan besar nya fermentasi yang berlangsung. Semakin banyak karbondioksida semakin besar fermentasi yang terjadi.

Pola yang berbeda pengaruh temulawak terhadap fermentasi alkohol ditunjukkan pada parameter $\mathrm{pH}$ yang menunjukkan semakin besar temulawak yang diberikan $\mathrm{pH}$ nya semakin tinggi, namun tidak berbeda nyata dan masih pada kisara nilai $\mathrm{pH}$ 3-4. Seperti diketahui bahwa $\mathrm{pH}$ merupakan tanda banyak-sedikitnya asam-asam organik yang tersisa atau diproduksi. Asam organik yang diproduksi dalam rangkaian fermentasi alkohol tersebut diantaranya adalah asam piruvat dan asetaldehida (Juwita, 2012; Fifendi $d k k ., 2013$ )

Pola yang mirip pada $\mathrm{pH}$ terjadi juga pada parameter banyak sel yang ada. Pada tabel 1 . tampak bahwa penambahan temulawak yang semakin besar akan meningkatkan pertumbuhan yang diperlihatkan oleh total sel khamir semakin meningkat seiring dengan peningkatan penambahan temulawak, meskipun hasilnya tidak beda nyata. Menurut Sjoekoer $d k k$., (2013) bahwa temulawak mampu meningkatkan konsumsi substrat nutrien molase yang diubah menjadi sel baru.

Pola perubahan sel hidup yang tersisa dan total sel yang mati tidak seiring dengan penambahan temulawak, namun seirama dengan peningkatan kandungan alkohol. Pada Tabel1 tampak sekali bahwa bila kadar alkoholnya tinggi maka sel yang mati juga tinggi sedangkan sel yang hidup rendah. Ini membuktikan bahwa khamir memang rentan dengan alkohol di atas 9\% dalam medium fermentasi. Hatmani (2000) menyatakan bahwa ada hambatan umpan balik pada fermentasi alkohol, yaitu produk akhir suatu metabolisma akan menghambat reaksi awal.

Alkohol mampu menyebabkan kerusakan sel-sel hati pada manusia pecandu alkohol. Pada sel khamir diduga alkohol akan melarutkan lemak yang menyusun membran sel khamir sehingga sel kehilangan daya selektifnya terhadap senyawa yang masuk, dan akhirnya lisis atau mati. Alkohol memiliki sifat mampu melarutkan lemak, sehingga digunakan untuk pembersih kulit dan benda-benda yang kotor. Alkohol juga dikenal sebagai desinfektans.

Temulawak berpengaruh bagi fermentasi alkohol lebih pada sebagai faktor pemacu pertumbuhan melalui pengaruhnya terhadap kegiatan konsumsi gula pada molase. Semakin banyak temulawak yang diberikan semakin banyak konsumsi gula, dan diiringi semakin banyak atau tinggi pertumbuhan. Temulawak tidak memiliki daya antimikroba yang besar (Sjoekoer dkk., 2013: Putra, 2014). 
Pengaruh temulawak terhadap produksi alkohol tidak nyata dan jelas polanya. Sehingga aplikasi hasil penelitian ini bukan pada khamir untuk industri alkohol, namun khamir untuk industri roti. Pada industri roti, sela khamir digunakan sebagai pengembang yang memanfaatkan karbondioksida (Endah dan Santoso, 2012). Hasil penelitian ini juga memperlihatkan penambahan temulawak 10-20 ml mampu memacu pelepasan karbondioksida yang besar, hampir dua kali lipat kontrol.

\section{Simpulan dan Saran}

\section{Simpulan}

Penambah sari temulawak terhadap substrat molase untuk fermentasi alkohol menggunakan khamir Saccharomyces cerevisiae berpengaruh positif bagi pertumbuhan sel khamir, dan berpengaruh negatif bagi produksi alkoholnya.

\section{Saran}

Disarankan untuk meneliti lebih lanjut menggunkan kadar kurang dari $10 \mathrm{ml}$ untuk melihat pengaruh temulawak terhadap fermentasi alkohol dan meneliti lebih lanjut karakteristik khamir yang ditumbuh pada substrat ditambah temulawak serta dampak minuman beralkohol dari temulawak ini terhadap para pecandu atau hewan uji.

\section{Ucapan Terima Kasih}

Terima kasih diucapkan kepada Universitas Atma Jaya Yogyakarta yang telah mendanai penelitian ini.

\section{Daftar Pustaka}

Adilia, Nurmiati, R. dan Agustien, A. 2013. Uji Antimikroba Curcuma spp Terhadap pertumbuhan Candida albicans, Staphylococcus aureus dan Escherichia coli. Jurnal Biologi, 2 (1): $1-7$.

Adipratama, D.N. 2009. Pengaruh Ekstrak Etanol Temulawak (Curcuma xanthorirhiza Roxb) Terhadap Jumlah dan Diferensiasi Leukosit Ayam Petelur (Gallus gallus) Skripsi Fak. Kedokteran Hewan. Institut Pertanian Bogor.
Bergman, L.W. 2001. Growth and Maintenance of YeastTwo Hybrid Systems. Vol. 177 of The series Methods in Molecular Biology pp 9-14.

Ceirwyn, S.J. 1995. Analytical Chemistry of Foods. Blackie Acad and Professional, London.

Endah, P. dan Santoso, H. 2012. Optimasi Fermentasi Pada Pembuatan Ekstrak Temulawak Sebagai bahan Baku Es Krim. Jurnal Ilmu-ilmu Pertanian 16 (2): 91-99.

Fifendy, M., Eldini dan Irdawati. 2013. Pengaruh pemanfaatan molase terhadap jumlah mikroba dan ketebalan nata pada Teh Kombucha. Prosiding Semirata FMIPA (Universitas Lampung).

Hatmanti, A. 2000. Pertumbuhan Saccharomycopsos fibuligera dan Saccharomyces cerevisiae pada Fermentasi Etanol Kulit Pisang Cavendish pada $\mathrm{pH}$ awal yang berbeda. Widyariset, vol 1 . Kandidat Peneliti, Balitbang Lingungan Laut, Puslitbang Oseanologi.

Ho D. H N. And Powell, C. 2014. The Effect Temperature on The Growth Characteristic of Etanol Producing Yeast Strain. International Journal of Renewable Energy and Environmenta Engineering 2 (1) :1-6

Ismaryana, Alfitri, S., Rahman, D. dan Safari, A. 2012. Kinerja Fermentasi Ragi Saccharomyces cerevisiae Pada Media VHG dengan Variasi Ekstrak Ragi Sebagai Sumber Nitrogen Untuk Produksi Etanol., Conference Paper. Research Gate.

Juwita, R. 2012. Studi Produksi Alkohol dari Tetes Tebu (Saccharum officinarum L) Selama Proses Fermentasi . Skripsi Jurusan Teknologi Pertanian: Fakultas Pertanian, Universitas Hasanuddin. Makassar.

Pinem, L.H. 1999. Studi Fermentasi Alkohol Dari temulawak Untuk Mempersiapkan Bahan Minuman Anggur. Skripsi Fak. Biologi Univ. Kristen Duta Wacana Yogyakarta.

Prasetyorini, I.Y. Wiendarlina dan Peron, A.B. 2011. Toksisitas bebrbagai Ekstrak Rimpang Cabang Temulawak (Curcuma xanthorhizza Roxb) Pada Larva Udang. Fitofarmaka 1 (2): 14-21.

Putra, I.N.P. 2014. The Potential Of Plant Extracts as Food Products Preservative. Media Ilmiah Teknologi Pangan. 1 (1): 81-95.

Ramdja, A.F., Aulia, R.M.A. dan Mulya, P. 2009. Ekstraksi Kurkumin Dari Temulawak Menggunakan Etanol. Jurnal Teknik Kimia, 3 (16): 52-58.

Sebayang, F. 2006. Pembuatan Etanaol Dari Molase Secara Fermentasi Menggunakan Sel Saccharomyces cerevisiae Pada Kalsium Alginat. Jurnal Teknologi Proses, 5 (2): 68-74. 
Atmodjo dkk.,

Simanjuntak, R. 2009. Studi Pembuatan Etanol dari Limbah Gula (Molase). Skripsi Fakultas Pertanian USU (USU Repository).

Sjoekoer, M., Dzen, S., Wibowati, A. dan Purwarini, W. 2013. Efek Antimikrobia Ekstrak Rimpang Temulawak (Curcuma xanthorrhiza) Terhadap Salmonella typhi. Animal Agriculture Journal, 2 (1): 168 - 174. Online at : http://ejournals1.undip.ac.id/index.php/aaj
Sudarmadji, S., Harjadi, B. dan Suhardi. 1997. Prosedur Anlisa Untuk Bahan Makanan dan Pertanian. Penerbit Liberty. Yogyakarta.

Sunaryati, A. Muktiani dan Achmadi, J. 2006. Suplementasi Temulawak Dan Zn Proteinat Terhadap Konsumsi dan Produksi Energi Susu Pada Sapi Perah. makalah S2 Universitas Indonesia

Wardani, A.K. dan Fenty N.E.P. 2013. Produksi Etanol Dari Tetes Tebu oleh Saccharomyces cerevisiae Pembentuk Flok (NRRL - Y 265). AGRITECH, (33):131-139 